\title{
Efektifitas Daya Pisah Electric Separating Sperm (ESS) terhadap Spermatozoa Kromosom X dan Y pada Kambing Sapera
}

\author{
(THE EFFECTIVENESS OF POWER OF ELECTRIC SEPARATING SPERM (ESS) \\ SPRAY ON CHROMOSOME X AND Y SPERMATOZOA ON SAPERA GOATS)
}

\author{
Fahlevi Lailiyah $^{1 *}$, Pudji Srianto², Amung Logam Saputro³ ${ }^{3}$, Sri Pantja Madyawati², \\ Bodhi Agustono ${ }^{4}$, Ragil Angga Prastiya ${ }^{2}$ \\ ${ }^{1}$ Bachelor of Veterinary Medicine, \\ ${ }^{2}$ Department of Veterinary Reproduction, \\ ${ }^{3}$ Department of Clinic and Animal Hospital, \\ ${ }^{4}$ Department of Animal Husbandry, \\ Faculty of Veterinary Medicine, Universitas Airlangga, \\ UNAIR C-Campus Mulyorejo, Surabaya, Jawa Timur, Indonesia, 60115 \\ Telp. (031)5993016, Fax. (031)5993015 \\ *Corresponding author: fahlevi.lailiyah-2014@fkh.unair.ac.id
}

\begin{abstract}
Abstrak
Penelitian ini bertujuan untuk mengetahui efektifitas pemisahan alat Electric Separating Sperm (ESS) terhadap spermatozoa kromosom X dan Y pada sisi anoda dan katoda dengan variabel meliputi presentase viabilitas, motilitas, abnormalitas dan morfometri spermatozoa. Metode pengambilan semen menggunakan vagina buatan, kemudian dilakukan pemeriksaan makroskopis dan mikroskopis, apabila menunjukkan hasil yang baik dilanjutkan dengan pengenceran semen dengan Tris Kuning Telur dan dilakukan pemisahan. Terdapat tiga perlakuan pada penelitian ini yaitu P1 (3 menit), P2 (7 menit), P3 (10 menit) dengan enam kali pengulangan pada sisi anoda dan katoda. Data pada tiap variabel (viabilitas, motilitas dan abnormalitas) diperiksa menggunakan analisis statistik ANOVA dan untuk melihat adanya pemisahan spermatozoa kromosom X dan $\mathrm{Y}$ dilakukan pengukuran terhadap kepala menggunakan morfometri. Hasil pemisahan tertinggi yaitu pada P3 dengan perbandingan pemisahan X : Y sejumlah 65,00:35,00 pada sisi katoda, kemudian pada sisi anoda persentase perbandingan $X: Y$ yaitu 59,00:41,00. Hasil kualitas spermatozoa setelah pemisahahn menunjukkan presentase viabilitas terbaik terdapat pada P1 yaitu $75,00^{\mathrm{a}} \pm 2,00$ pada sisi anoda dan $76,50^{\mathrm{a}} \pm 2,17$ pada sisi katoda. Motilitas spermatozoa P1 menunjukkan motilitas progresif spermatozoa dengan rataan $60,83^{\mathrm{a}} \pm 2,04$ pada anoda dan $61,67^{\mathrm{a}} \pm 2,58$ pada sisi katoda. Presentase abnormalitas tidak menunjukkan perbedaan yang signifikan antar perlakuan.
\end{abstract}

Kata kunci: sperma, pemisahan, ESS, kualitas, morfometri

\begin{abstract}
This study aimed to determine the effectiveness of separation of Electric Separating Sperm (ESS) on X and $Y$ chromosome spermatozoa on the side of the anode and cathode with variables including the percentage of viability, motility, abnormalities and morphometry of spermatozoa. Methods of collect semen using artificial vagina, then performed macroscopic and microscopic examination, if it shows good results followed by dilution of cement with Yellow Trist Egg and separation. There are three treatments in this study, namely P1 (3 minutes), P2 (7 minutes), P3 (10 minutes) with six repetitions on the side of the anode and cathode. Data on each variable (viability, motility and abnormalities) were examined using ANOVA statistical analysis and to see the separation of $X$ and $Y$ chromosome spermatozoa measurements were made on the head using morphometry. The highest separation result is in $P 3$ with a ratio of $X: Y$ separation of 65,00:35,00 on the cathode side, then on the anode side the percentage ratio of $X: Y$ is 59,00:41,00. The results of the quality of spermatozoa after separation showed the best percentage of viability was found at P1 which was 75,00 $\pm 2,00$ on the anode side and $76,50^{a} \pm 2,17$ on the cathode side. Spermatozoa motility $P 1$ shows spermatozoa progressive motility with a mean of 60,83 $3^{a}+2,04$ at the anode and $61,67^{a} \pm 2,58$ at the cathode side. Percentage abnormalities do not show significant differences between treatments.
\end{abstract}

Key words: sperm, separation, ESS, quality, morphometry 


\section{PENDAHULUAN}

Kambing sapera merupakan kambing hasil persilangan antara kambing jantan Saanen dengan kambing betina PE. Persilangan antara kedua jenis kambing ini menghasilkan sifat mudah beradaptasi terhadap iklim di Indonesia, memiliki postur tubuh yang besar dan kuat dan mampu memproduksi susu yang tinggi dengan waktu laktasi yang lebih lama serta mudah untuk dibudidayakan (Batubara dkk., 2016). Kemampuan produksi susu kambing Sapera yang mampu mencapai 2-4 liter perhari dapat digunakan sebagai bahan pertimbangan untuk beternak kambing Sapera yang berfungsi sebagai kambing perah (Supriyati dkk., 2015).

Jenis kelamin kambing perah yang diperlukan untuk efisiensi biaya pemeliharaan yaitu berjenis kelamin betina. Hal ini bisa dilakukan dengan cara sexing terhadap spermatozoa sebelum dilakukan inseminasi buatan (Afiati, 2004). Teknologi sexing pada spermatozoa memudahkan peternak dalam usaha peternakan, karena jenis kelamin bibit yang diinginkan bisa disesuaikan dengan tujuan peternakan tersebut. (Pasaribu dkk., 2014).

Sexing spermatozoa dapat dilakukan dengan memanfaatkan muatan listrik yang terdapat pada permukaan sel spermatozoa. Spermatozoa jika diletakkan pada daerah yang mengandung muatan listrik, maka spermatozoa $\mathrm{Y}$ akan berpindahkan menuju anoda (Aitken and Ainsworth, 2012). Muatan yang terdapat pada spermatozoa dipengaruhi oleh kandungan ion kalium intraseluler. Spermatozoa yang memiliki kandungan ion kalium lebih besar, diasumsikan memiliki muatan positif sehingga akan berenang menuju sisi katoda. Begitu pula sebaliknya, pada spermatozoa yang mengandung lebih sedikit ion kalium dianggap memiliki muatan negatif sehingga akan bergerak menuju sisi anoda (Saputro, 2012). Indikator untuk mengetahui kromosom penentu jenis kelamin yaitu dapat dilihat dari ukuran kepala spermatozoa. Ukuran kepala spermatozoa pada kambing memiliki ratarata panjang $8,5 \mu \mathrm{m}$, lebar $4,2 \mu \mathrm{m}$, luas $29 \mu \mathrm{m}$, dan keliling 17 $\mu \mathrm{m}$ (Hidalgo and Dorado, 2009).
Electric Separating Sperm (ESS) bekerja pada tegangan listrik rendah yaitu 1.5 Volt. Alat ini mampu memisahkan kromosom $\mathrm{X}$ dan $\mathrm{Y}$ pada spermatozoa dalam waktu yang relatif singkat dan kualitas yang tidak berbeda nyata dengan kontrol pada domba Merino (Saputro, 2012).

Berdasarkan latar belakang diatas perlu dilakukan penelitian mengenai efektifitas pemisahan alat Electric Separating Sperm (ESS) terhadap spermatozoa kromosom X dan Y pada kambing Sapera.

\section{METODE PENELITIAN}

\section{Alat dan Bahan}

Alat dan bahan penelitian ini adalah semen kambing Sapera, Tris Kuning Telur, aquades, $\mathrm{NaCl}$ fisiologis, eosin-negrosin, vaselin, vagina buatan, mikroskop Olympus ${ }^{\circledR}$ CX23, mikroskop Nikon H600L yang dilengkapi dengan kamera obtilab dan aplikasi NIS-Elements BR 4.10.00, kertas $\mathrm{pH}$, kaca obyek, kaca penutup, pembakar bunsen, mikropipet, tabung reaksi, spektrofotometer, stopwatch dan Electric Separating Sperm.

\section{Pemeriksaan Spermatozoa}

Pemeriksaan makroskopis meliputi volume, warna, $\mathrm{pH}$ dan konsistensi. Pemeriksaan mikroskopis meliputi viabilitas, motilitas, abnormalitas, morfometri dan konsentrasi. Pemeriksaan viabilitas, motilitas dan abnormalitas dilakukan dengan menggunakan Olympus ${ }^{\circledR}$ CX23 dengam perbesaran 400 kali. Pemeriksaan konsentrasi spermatozoa menggunakan spektrofometer dengan panjang gelombang $546 \mathrm{~nm}$ (Susilowati dkk., 2010).

Pemeriksaan morfometri spermatozoa sapi Rambon dilakukan dengan membuat preparat pewarnaan eosin negrosin. Identifikasi morfometri spermatozoa menggunakan mikroskop Nikon H600L dengan skala mikrometer perbesaran 1000X. Pengukuran morfometri meliputi panjang dan lebar kepala spermatozoa (Putri dkk., 2015).

Penentuan spermatozoa kromosom $\mathrm{X}$ dan $\mathrm{Y}$ berdasarkan ukuran panjang kali lebar (pxl) 
kepala spermatozoa, apabila kepala spermatozoa berukuran lebih besar atau sama dengan rata-rata $(\mathrm{pxl} \geq \overline{\mathrm{x}})$ maka dikategorikan sebagai spermatozoa berkromosom $\mathrm{X}$ dan apabila ukuran kepala spermatozoa lebih kecil dibandingkan rata-rata $(\mathrm{pxl}<\overline{\mathrm{x}})$ maka dikategorikan spermatozoa berkromosom Y (Mahaputra dkk, 2012).

\section{Analisis Data}

Data dianalisis menggunakan SPSS versi 22 meliputi uji statistik Analysis of Varian
(ANOVA) kemudian dilanjut dengan menggunakan uji Duncan (Kusriningrum, 2012).

\section{HASIL DAN PEMBAHASAN}

Struktur spermatozoa terdiri dari kepala dan ekor. Bagian kepala mengandung DNA yang berisi kromosom $\mathrm{X}$ dan kromosom $\mathrm{Y}$ yang berperan dalam menentukan jenis kelamin anakan.

Tabel 1. Rataan hasil pengukuran morfometri spermatozoa kambing Sapera

\begin{tabular}{|c|c|c|c|}
\hline \multirow[t]{2}{*}{ Kutub } & \multirow{2}{*}{$\begin{array}{c}\text { Jumlah } \\
\text { spermatozoa }\end{array}$} & \multicolumn{2}{|c|}{$\begin{array}{c}\text { Ukuran kepala spermatozoa } \\
\text { (Rataan } \pm \text { simpangan baku) }\end{array}$} \\
\hline & & Panjang & Lebar \\
\hline Anoda & 100 & $8,64 \pm 2,32$ & $4,00 \pm 0,27$ \\
\hline Katoda & 100 & $8,68 \pm 0,35$ & $4,03 \pm 0,28$ \\
\hline \multicolumn{4}{|c|}{ Tabel 2. Viabilitas spermatozoa } \\
\hline \multirow{2}{*}{ Perlakuan } & \multicolumn{3}{|c|}{ Viabilitas spermatozoa (Rataan \pm simpangan baku) } \\
\hline & \multicolumn{2}{|c|}{ Anoda } & Katoda \\
\hline $\mathrm{P} 1$ & \multicolumn{2}{|c|}{$75,00^{\mathrm{a}} \pm 2,00$} & $76,50^{\mathrm{a}} \pm 2,17$ \\
\hline $\mathrm{P} 2$ & \multicolumn{2}{|c|}{$72,50^{\mathrm{ab}} \pm 1,52$} & $73,33^{\mathrm{ab}} \pm 3,14$ \\
\hline P3 & \multicolumn{2}{|c|}{$62,67^{\mathrm{b}} \pm 7,03$} & $62,00^{\mathrm{b}} \pm 2,83$ \\
\hline
\end{tabular}

Tabel 3. Motilitas spermatozoa

\begin{tabular}{ccc}
\hline Perlakuan & $\begin{array}{c}\text { Motilitas spermatozoa }(\text { Rataan } \pm \text { simpangan baku) } \\
\text { Anoda }\end{array}$ & Katoda \\
\hline P1 & $60,83^{\mathrm{a}} \pm 2,04$ & $61,67^{\mathrm{a}} \pm 2,58$ \\
P2 & $55,83^{\mathrm{b}} \pm 2,04$ & $56,67^{\mathrm{b}} \pm 2,58$ \\
P3 & $46,67^{\mathrm{c}} \pm 5,16$ & $47,50^{\mathrm{c}} \pm 4,18$ \\
\hline
\end{tabular}

Tabel 4. Abnormalitas spermatozoa

\begin{tabular}{ccc}
\hline Perlakuan & $\begin{array}{c}\text { Abnormalitas spermatozoa (Rataan } \pm \text { simpangan baku) } \\
\text { Anoda }\end{array}$ & Katoda \\
\hline P1 & $3,00^{\mathrm{a}} \pm 1,41$ & $2,67^{\mathrm{a}} \pm 1,21$ \\
P2 & $3,33^{\mathrm{a}} \pm 1,03$ & $2,67^{\mathrm{a}} \pm 1,63$ \\
P3 & $3,67^{\mathrm{a}} \pm 1,03$ & $3,50^{\mathrm{a}} \pm 1,76$ \\
\hline
\end{tabular}

Tabel 5. Persentase jumlah spermatozoa $X$ dan $Y$ pada sisi anoda dan katoda

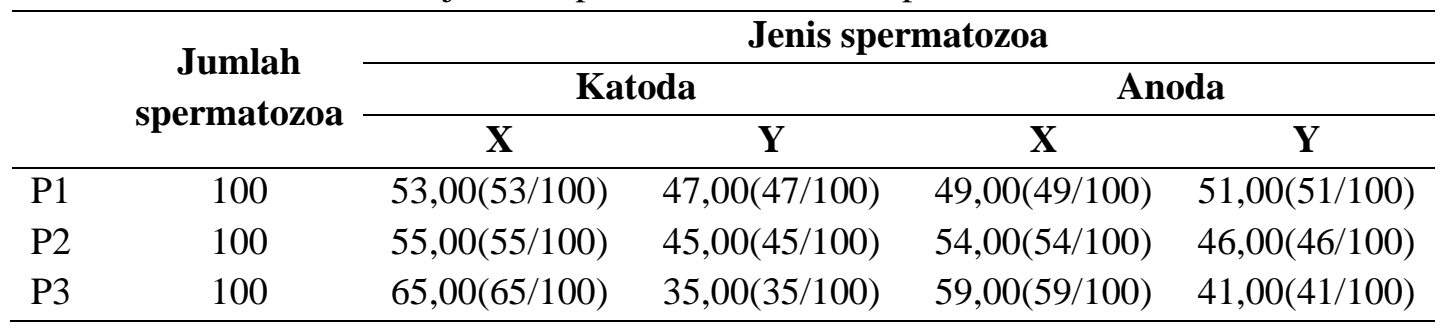


Kepala spermatozoa ditutupi oleh dua lapis embrane, membran dalam dan membran luar yang dibatasi oleh matriks akrosom. Matriks akrosom mengandung enzim hyaluronidase dan akrosin yang berfungsi untuk menembus zona pelusida saat fertilisasi (Ismudiono dkk., 2010).

Pengukuran morfometri dilakukan pada kepala spermatozoa. Pengukuran dilakukan terhadap panjang dan lebar kepala spermatozoa (Putri dkk., 2015). Hasil pengukuran menunjukkan rataan panjang kepala spermatozoa kambing Sapera pada daerah anoda yaitu $8,64 \pm 2,32$ dengan lebar $4,00 \pm 0,27$. Pengukuran rataan panjang kepala spermatozoa pada daerah katoda yaitu 8,68 $\pm 0,35$ dengan lebar 4,03 $\pm 0,28$.

Ukuran kepala spermatozoa yang lebih besar sama dengan rataan maka diidentifikasikan sebagai spermatozoa $\mathrm{X}$ sedangkan spermatozoa dengan ukuran kepala lebih kecil dibandingkan rataan, maka diidentifikasikan sebagai spermatozoa Y (Susilawati, 2014). Berdasarkan hal tersebut maka spermatozoa yang terdapat pada sisi anoda diidentifikasikan sebagai spermatozoa Y, sedangkan pada sisi katoda diidentifikasikan sebagai spermatozoa $\mathrm{Y}$.

Hasil statistik ANOVA menunjukkan tidak terdapat perbedaan antara P1 sisi anoda $\left(75,00^{\mathrm{a}} \pm 2,00\right)$ dan katoda $\left(76,50^{\mathrm{a}} \pm 2,17\right)$ dengan P2 pada kedua sisi ( $>0,05)$, tetapi ditemukan adanya perbedaan pada P1 sisi anoda dan katoda dengan P3 sisi anoda $\left(62,67^{\mathrm{b}} \pm 7,03\right)$ dan katoda $(\mathrm{p}<0,05)$. Sedangkan P2 sisi anoda $\left(72,50^{\mathrm{ab}} \pm 1,52\right)$ dan katoda $\left(73,33^{\mathrm{ab}} \pm 3,14\right)$ dengan P3 sisi anoda $\left(62,67^{\mathrm{b}} \pm 7,03\right)$ dan katoda $\left(62,00^{b} \pm 2,83\right)$ tidak terdapat perbedaan $(p>0,05)$. Dari ketiga perlakuan diatas didapatkan P1 pada kedua sisi memiliki viabilitas tertinggi. Hal ini disebabkan karena viabilitas pada spermatozoa dipengaruhi oleh energi yang dihasilkan oleh spermatozoa tersebut secara aerob maupun anaerob. Pergerakan spermatozoa yang terjadi secara terus-menerus akibat adanya proses pemisahan dengan listrik akan menyebabkan penurunan energi (ATP) (Saputro, 2012).

Metabolisme energi tersebut akan meningkatkan kandungan asam laktat. Penumpukan asam laktat tersebut bisa menyebabkan perubahan $\mathrm{pH}$ menjadi asam yang bisa menyebabkan kematian terhadap spermatozoa (Inonie dkk., 2016). Penilaian terhadap spermatozoa yang hidup atau mati didasarkan atas kemampuan spermatozoa tersebut menyerap zat warna eosin-negrosin. Spermatozoa hidup tidak menyerap zat warna, sedangkan spermatozoa yang mati akan menyerap warna karena permeabilitas dinding spermatozoa meningkat saat sel tersebut mati (Layla dan Aminah, 2002).

Hasil pemeriksaan motilitas spermatozoa berdasarkan analisis statistik ANOVA menunjukkan penurunan persentase motilitas pada tiap perlakuan, hal ini disebabkan karena adanya aliran listrik saat proses pemisahan spermatozoa sehingga mampu meningkatkan suhu. Penumpukan asam laktat pada kondisi anaerob dan $\mathrm{CO} 2$ pada kondisi aerob yang terbentuk karena metabolisme spermatozoa untuk menghasilkan energi, sehingga menghambat pergerakan spermatozoa (Pasupuleti, 2007).

Data hasil abnormalitas spermatozoa pada tiap kelompok perlakuan menunjukkan angka rataan persentase abnormalitas dan simpangan baku berturu-turut adalah P1 pada anoda $3,00^{\mathrm{a}} \pm 1,41$ dan pada sisi katoda $2,67^{\mathrm{a}} \pm 1,21, \mathrm{P} 2$ anoda menunjukkan jumlah $3,33^{\mathrm{a}} \pm 1,03$ dan katoda 2,67a $\pm 1,63$, P3 menunjukkan hasil $3,67^{\mathrm{a}} \pm 1,03$ dan $3,50^{\mathrm{a}} \pm 1,76$.

Persentase abnormalitas tidak berbeda nyata pada tiap perlakuan hal ini disebabkan karena kuat arus listrik yang diberikan pada perlakuan termasuk kecil dan dalam waktu yang relatif singkat (Saputro, 2012).

Persentase pemisahan tertinggi terdapat pada P3. Persentase spermatozoa $X$ pada sisi katoda yaitu 65,00, sedangkan spermatozoa Y pada sisi katoda yaitu 35,00. Persentase pada spermatozoa $\mathrm{X}$ pada sisi anoda yaitu 59,00 dan spermatozoa Y anoda sejumlah 41,00. Hal ini dipengaruhi karena adanya muatan yang terdapat pada spermatozoa. Muatan ini dipengaruhi oleh kandungan ion kalium intraseluler. Spermatozoa yang memiliki kandungan ion kalium lebih besar, diasumsikan memiliki muatan positif sehingga akan berenang menuju sisi katoda. Begitu pula sebaliknya, pada spermatozoa yang 
mengandung lebih sedikit ion kalium dianggap memiliki muatan negatif sehingga akan bergerak menuju sisi anoda (Saputro, 2012).

\section{KESIMPULAN}

Hasil penelitian menunjukkan hasil Sexing menggunakan Electric Separating Sperm (ESS) berpengaruh terhadap kualitas spermatozoa kambing sapera kromosom $\mathrm{X}$ dan $\mathrm{Y}$ pada sisi anoda dan katoda dengan hasil terbaik didapatkan pada P1 (3 menit). Sexing menggunakan Electric Separating Sperm (ESS) efektif dilakukan untuk memisahkan spermatozoa kambing Sapera kromosom X dan Y pada sisi anoda dan katoda dengan presentase pemisahan tertinggi terdapat pada P3 (10 menit).

\section{UCAPAN TERIMA KASIH}

Peneliti mengucapkan terima kasih kepada PSDKU Banyuwangi Universitas Airlangga dan Bumi Kesilir Farm atas izin yang diberikan untuk dilakukan penelitian.

\section{DAFTAR PUSTAKA}

Afiati, F. 2004. Proporsi dan Karakteristik Spermatozoa X dan Y Hasil Separasi Kolom Albumin. Media Peternakan, 27(1): 17-20.

Aitken, R.J. and C.J. Ainsworth. 2012. Sperm Cell Separation by Electrophoresis. United State. p371.

Batubara, A., S. Nasution, Subandriyo, I. Inounu, B. Tiesnamurti, dan A. Anggraeni. 2016. Kambing Peranakan Etawah (PE). IAARD Press. Jakarta.

Hidalgo, M. and J. Dorado. 2009. Objective Assesment of Goat Sperm Head Size by Computeri-Assisted Sperm Morphometry Analysis. University of Cardoba. Spanyol. 87: 109.

Inonie, R.I., L.O. Baa, dan T. Saili. 2016. Kualitas Spermatozoa kambing boerawa dna kambing kacang pada penggunaan TrisKuning Telur yang berbeda.

Ismudiono, P. Srianto, H. Anwar, S.P. Madyawati, A. Samik, dan E. Safitri. 2010. Fisiologi Reproduksi pada Ternak. Universitas Airlangga Press. Surabaya.

Kusriningrum, R.S. 2010. Perancangan Percobaan. Universitas Airlangga Press. Surabaya.

Layla, Z., dan S. Aminah. 2002. Uji Kualitas Sperma dan Penghitungan Jumlah Pengencer dalam Upaya Menentukan Keberhasilan Inseminasi Buatan. Temu Teknis Fungsional Non Peneliti. Balai Penelitian Ternak. Bogor.

Mahaputra, L., M. Mafruchati, N. Triakoso, dan R.D. Aries. 2012. Pemisahan Spermatozoa Sapi Limousin yang Memiliki Kromosom X dan Y dengan Percoll dan Putih Telur Ayam. Jurnal Bina Praja, 14(3): 172-175.

Pasaribu, E., Dasrul dan G. Riady. 2014. Pengaruh Pemisahan Spermatozoa X Dan Y Dengan Menggungakan Metode Swim Up Terhadap Kualitas Spermatozoa Kambing Peranakan Ettawa (PE). Jurnal Medika Veterinaria, 8(2): 102-103.

Pasupuleti, V. 2007. Role of Glycolysis and Respiration in Sperm Metabolism and Motility. Thesis. Kent State University.

Putri, R.D.A., M. Gunawan, dan E.M. Kaiin. 2015. Uji Kualitas Sperma Sexing Sapi Friesian Holstein (FH) Pasca Thawing. Prosiding Seminar Nasional Masyarakat Biodiversitas Indonesia. 1: 2059.

Saputro, A.L. 2012. Kualitas Spermatozoa Domba Merino pada Sisi Anoda Hasil Pemisahan dengan Teknik ESS (Electric Separating Sperm). Skripsi. Universitas Airlangga Fakultas Kedokteran Hewan. Surabaya. 
Supriyati, R. Krisnan, dan L. Praharani. 2015. Konsumsi Nutrien, Produksi Susu dan Komposisi Tiga Genotipe Kambing Perah. Prosiding Seminar Nasional Teknologi Peternakan dan Veteriner. Bogor. Hal.357363.

Susilowati, S., Hardijanto, T.W. Suprayogi, T.
Sardjito, dan T. Hernawati. 2010. Penuntun Praktikum Inseminasi Buatan. Universitas Airlangga Press. Surabaya.

Susilawati, T. 2014. Sexing Spermatozoa Hasil Penelitian Laboratorium dan Aplikasi pada Sapi dan Kambing. Universitas Brawijaya Press. Malang. 